\title{
Variation in helminth susceptibility of indigenous chickens in Kano and Jigawa States of Nigeria \\ ${ }^{* 1}$ Ibrahim, A. A., ${ }^{2}$ Mbap, S. T., ${ }^{2}$ Ibrahim, T. and ${ }^{2}$ Mancha, Y. P. \\ ${ }^{1}$ Department of Animal Science, Federal University, Dutse. P.M.B. 7156, Dutse, Jigawa State, Nigeria. \\ Department of Animal Production, Abubakar Tafawa Balewa University, Bauchi. Bauchi State, Nigeria. \\ *Corresponding author: talk2aai@yahoo.com
}

Abstract

This study was carried out to identify the helminth parasites and burden associated with five indigenous chicken strains namely normal feathered Fulani ecotypes, naked neck, dwarf and frizzle kept under free-range system in six local government areas of Kano and Jigawa States. A total of 540 fresh faecal samples were collected from the gastrointestinal tract. Faecal egg count (quantitative examination) was carried out using the modified McMaster technique with flotation solution. All the helminths (cestodes and nematodes) were examined under light microscope and identified on the basis of helminthological keys. Worm count, $E P G$, Packed cell volume (PCV), total serum proteins and albumin were used to assess chicken susceptibility to worm infection. Significant differences were observed among the chicken strains for egg per gramme (EPG), cestodes and nematodes. The highest EPG (119.80) was observed in naked neck chickens, followed by frizzled (114.18), dwarf (62.86), normal feathered (30.80) and Fulani ecotypes (0.71). Frizzled chickens had higher mean cestode (7.96) count than the other strains. Dwarf chickens were significantly $(P<0.05)$ more susceptible to nematode infection. Higher EPG (60.55) and worm burden (cestode, 6.08) was found in males than females. The high gene flow and low differentiation between Fulani ecotype and normal feathered and, naked neck and frizzled buttressed the assertion that the similarity in EPG between them were because of genetic closeness. Susceptibility to worm infection in the study measured by the prevalence and EPG was therefore genetically controlled. There were generally negative and low correlations between egg and adult worm counts with haematological indices considered. Thus, blood parameters do vary in response to helminth infection and could be good measures of susceptibility.

Keywords: Helminth parasites, EPG, worm burden, gene flow, susceptibility

\section{Variation de la susceptibilité à Helminthe des poulets autochtones dans les États de Kano et Jigawa du Nigéria}

\section{Résumé}

Cette étude a été réalisée pour identifier les parasites de Helminthe et le fardeau associé à cinq souches de poulet autochtones, à savoir des écotypes Fulani à plumes normaux, un nuque nu, un nain et une frisée maintenus sous un système de liberté dans six zones gouvernementales locales des États de Kano et Jigawa. Un total de 540 échantillons fécaux frais ont été collectés à partir du tractus gastro-intestinal. Le nombre d'œufs fécaux (examen quantitatif) a été réalisé en utilisant la technique modifiée McMaster avec une solution de flottation. Tous les helminthes (cestodes et nématodes) ont été examinés sous un microscope léger et identifiés sur la base de clés helminthologiques. Le nombre de ver, EPG, volume de cellules emballé (VCE), les protéines sériques totales et l'albumine ont été utilisées pour évaluer la sensibilité au poulet à une infection de vers. Des différences significatives ont été observées parmi les souches de poulet pour l'œuf par gramme (EPG), des cestodes et des 


\section{Variation in helminth susceptibility of indigenous chickens}

nématodes. Le plus haut $\operatorname{EPG}(119,80)$ a été observé dans des poulets de cou nu, suivis de frisanges $(114,18)$, de nains $(62,86)$, d'écotypes normaux à plumes $(30,80)$ et de Fulani $(0,71)$. Les poulets frongettes avaient une cestode moyenne moyenne $(7,96)$ comptant que les autres souches. Les poulets nains étaient significativement $(p<0,05)$ plus susceptibles d'infection nématode. L'EPG $(60,55)$ et la charge de ver supérieur (CESTOD, 6,08) ont été trouvés chez les poulets que les poules. Le flux de gènes élevé et la faible différenciation entre les écotypes Fulani et la normale à plumes normaux et à la nuque nue et à contreforts librizatés l'affirmation selon laquelle la similitude dans $E P$ G entre elles étaient à cause de la proximité génétique. La susceptibilité à une infection de vers dans l'étude mesurée par la prévalence et l'EPG a donc été contrôlée génétiquement. Il y avait généralement des corrélations négatives et faibles entre le nombre de ver d'œufs et d'adultes avec des indices hématologiques considérés. Ainsi, les paramètres sanguins varient en réponse à l'infection d'helminthe et pourraient être de bonnes mesures de susceptibilité.

Mots-clés: Parasites helminthe, EPG, Fardeau de ver, flux de gènes, susceptibilité

\section{Introduction}

Poultry production in tropical countries is based on the traditional scavenging system and chickens are the most important species (Lamidi et al., 2014). The system provides meat, eggs, organic manure of high quality and is a reliable source of petty cash. The village chickens also fulfil a number of intangible benefits (Dube et al., 2010). These include pest control, uses in traditional ceremonies and festivals (Muchadeyi et al., 2004) because of few social and religious taboos against them (Mafu and Masika, 2003). Strategic increase in productivity of rural chickens will assist poverty alleviation; improve household - security, and protein intake of the rural communities, and in the long run curb urban migration (Dube et al., 2010). Despite the importance of local chickens to humans, information on their genetic makeup and variability with respect to performance, adaptability, resistance to diseases are scarce (Alipanah et al., 2011). In addition, very little strategies have been adopted geared at conservation. The efficiency of indigenous poultry farming in developing countries, and indeed in Nigeria however is affected by the presence of parasites (and other factors) (Permin and Hansen, 1998). High prevalence of helminth parasites have been reported in free- range chickens in several developing countries (Abdelqadir et al., 2008; Mukaratirwa and Hove, 2009). Iqbal et al. (2004) reported that helminths are frequently found in indigenous and exotic poultry and vary from 1 to $85 \%$ depending on geographical location. Parasitic diseases in chickens however, are often neglected because they are rarely lethal (Tesfaheywet et al., 2012). Low gastrointestinal infections nonetheless contribute to subclinical conditions (Pinckney et al., 2008), while heavy loads have devastating effect on growth, egg production and overall health (Pandey et al., 1992; Permin et al., 1997). Chickens pick up eggs of parasite by ingesting contaminated feed, water, litter and intermediate hosts such as snails, earth worms, or other insects (Butcher and Miles, 1992). Helminth parasites are commonly divided into three main groups; Nematodes (Roundworms), Cestodes (Tapeworms) and Trematodes (Fluke). Nematodes constitute the most important group in poultry both in number of species and extent of damage cause. The main genera include Capillaria heterakis, and Acaridia (Jordan and Pattison, 1996). The Cestode genera of importance are Railleitina and Hymenolepsis (Matur et al., 2010). Trematode infections however are not very common in domestic chickens as 


\section{Ibrahim, Mbap, Ibrahim and Mancha}

Prosthogonimus ntowi has been the only species reported from the belt of Ghana (Hodasi, 1978). Therefore, the present research was undertaken to identify the helminth parasites associated with the strains and determine whether worm burden is related to genotype an. Sex.

\section{Materials and methods Studyarea}

The study was conducted in six local government areas (LGAs) of Kano and Jigawa States. Geographically, the LGA's are situated between latitude $12^{\circ} 11^{\prime} \mathrm{N}$ and $12^{\circ} 58^{\prime} \mathrm{N}$, and longitude $7^{\circ} 38^{\prime} \mathrm{E}$ and $8^{\circ} 25^{\prime} \mathrm{E}$ (Olofin, 2007), at an average altitude of $485 \mathrm{~m}$ above sea level. The area is bordered to the north by Niger Republic; by Katsina state, south; Plateau, southeast; Bauchi east and Kaduna southwest

\section{Sample collection}

Six markets were purposely selected to represent the different geographical areas of the states. Chicken gastrointestinal tracts were subsequently collected. Samples collection was carried out from December, 2014 to January, 2016. Appropriate sample size was determined using the following expression (Permin and Hansen, 1998): $\mathrm{n}=\underline{\mathrm{Z}^{2}} \frac{\mathrm{PQ}}{\mathrm{L}^{2}}$

Where:

$\mathrm{n}=$ sample size,

$\mathrm{Z}=$ statistics for a level of confidence, usually stated at 1.96 ,

$\mathrm{P}=$ expected prevalence in the flock/population,

$\mathrm{Q}=1-\mathrm{P}$

$\mathrm{L}=$ required precision, e.g., the largest acceptable difference between the true and the estimated prevalence.

The helminth prevalence was not known; however, to maximize sample size, the expected prevalence was set at $90 \%$; precision was $5 \%$, and the confidence level, $95 \%$. The samples were transferred into $200 \mathrm{ml}$ bottles containing $10 \%$ formalin
(Plate IX), labeled and transported to the laboratory for examination. All samples were qualitatively and quantitatively analyzed according to the techniques described by Soulsby (1982) and Urquhart et al. (1996), where direct and concentration (simple floatation and egg count) methods were carried out using salt as ideal media for cestode and nematode eggs count.

\section{Faecal egg counts}

Faecal egg count FEC (quantitative examination) was carried out using the modified McMaster technique with flotation solution as described by Urquhart et al. (1996). About $2.0 \mathrm{~g}$ of faeces was weighed into a $30 \mathrm{~mL}$ polythene tube; $5 \mathrm{~mL}$ of water was added and thoroughly mixed with the aid of a glass rod to break it up. Water was added to the brim. The tube was covered and thoroughly shaken. The suspension was poured through a fine mesh sieve and the filtrate collected, agitated and centrifuged in a test tube at higher specific gravity for three minutes. It was allowed to bench for five minutes before counting to allow the eggs to rise in the floatation fluid. Both chambers of the slide were examined and numbers of eggs counted and, multiplied by 20 to determined egg per gramme (EPG)

\section{Worm identification and counts}

The gastrointestinal tract was opened longitudinally; visible helminths were collected followed by scraping off the mucosa and washing contents through a 63 $\mu$ aperture sieve. The remaining contents captured on the sieve were examined for the presence of helminth parasites under a stereo-microscope and observed helminths were collected and preserved in $70 \%$ ethyl alcohol. For identification, the helminths were mounted in drops of lactic acid, and the scoleces and mature proglottids of cestodes were cleared with lactic acid, nematodes were cleared using lacto-phenol. All the helminths were then examined under light microscope and were identified on the 


\section{Variation in helminth susceptibility of indigenous chickens}

basis of helminthological keys described by Dunn (1978), Soulsby (1982), Urquhart et al. (1987) and Permin and Hansen (1998).

\section{Evaluation of resistance/susceptibility to} worm infection

Worm count, EPG, packed cell volume (PCV), total serum proteins and albumin were used to assess chicken resistance to worm infection.

The PCV was determined according to the techniques described by Preston and Allonby (1978); Coles (1986). Blood samples $(2 \mathrm{~mL})$ were collected from the wing via disposable needle and syringe into tubes. Blood samples were centrifuged at a specific gravity for five minutes and count was determined using a Neubauer hemacytometer. The percentage of packed cells volume was recorded.

Total serum proteins and albumin were measured by colorimetric method using clinical chemistry kits (Human CompanyWiesbaden, Germany, 1985).

\section{Statistical analysis}

The statistical package for Social Sciences (SPSS, 2010) version 20.0 statistical software programme) was used for data analysis. The general linear model was employed to carry out analysis of variance on non-categorical measurements - worm count, EPG, PCV, TSP, ALB to test the effects of categorical factors. The model adopted was:

$\mathrm{Y}_{\mathrm{ijklm}}=\mu+\mathrm{C}_{\mathrm{i}}+\mathrm{B}_{\mathrm{j}}+\mathrm{e}_{\mathrm{ijklmn}}$

Where:

$\mathrm{Y}_{\mathrm{ijklm}}=$ is the observation on the ${ }_{\mathrm{ijklm}}$ th chicken

$\mu \quad=$ the overall mean

$\mathrm{C}_{\mathrm{i}}=$ effect of $\mathrm{i}^{\text {th }} \operatorname{strain}(\mathrm{i}=1,2,3,4,5)$

$B_{j}=$ effect of $j^{\text {th }} \operatorname{sex}(j=1,2)$

$\mathrm{e}_{\mathrm{ijklm}}=$ random error effects peculiar to each observation.

Investigating the genetic diversity of the Nigerian indigenous chickens using microsatellites markers

Sixty blood samples from the five populations were taken from the wing vein. The DNA sample were extracted and genotyped at 8 microsatellite loci choosing from those used by the EU funded project "Development of Strategy and Application of Molecular Tools to Assess Biodiversity in Chicken Genetic Resources, EC Contract Number BIO4-CT98-0342" and based on FAO's recommendation as outlined in MoDAD report (FAO, 2004). Allele frequency, mean number of alleles, expected and observed heterozygosity for all loci and populations were estimated to investigate the genetic diversity within strains. Wrights fixation indices $\left(\mathrm{F}_{\mathrm{IT}}, \mathrm{F}_{\mathrm{ST}}\right.$ and $\mathrm{F}_{\text {IS }}$ ) were calculated to define the genetic variance, the differentiation between populations. Pair-wise $\mathrm{F}_{\mathrm{ST}}$ were estimated to calculate the Nei's genetic distance and draw a dendrogram.

\section{Results}

\section{Effect of strain on worm burden}

The effect of strain of chickens on egg and adult worm counts (mean intensities) in the study area are as presented (Table 1). There was significant $(p<0.001)$ EPG variation by strain. The highest EPG was observed in naked neck chickens (119.80), followed by frizzled (114.18), dwarf (62.86), normal feathered (30.80) and Fulani ecotypes (0.71). Strain variation with regards to cestode was also significant $(\mathrm{P}<0.001)$. Frizzled chickens had higher mean cestode count (7.96) than the normal feathered, naked neck, Fulani ecotype and the dwarf with values of $5.37,4.51,3.38$ and 2.00 respectively. Dwarf chickens were significantly $(\mathrm{P}<0.05)$ more susceptible to nematode infection (3.29) as compared to 1.56, 1.20, 0.32 and 0.31 for normal feathered, Fulani ecotype, naked neck and frizzled birds respectively. Similarly, the effect of strain on mixed infection was significant $(\mathrm{P}<0.05)$. Frizzled chickens had the highest counts (8.27), followed by normal feathered, dwarf, naked neck and 


\section{Ibrahim, Mbap, Ibrahim and Mancha}

Fulani ecotype with values of 6.92, 5.29, 4.83 and 4.57 respectively.

\section{Effect of sex}

The effect of sex on worm burden (EPG) is depicted in Table 1. There was higher $(\mathrm{P}<0.01)$ egg count in males $(60.55)$ than females (24.21). For adult mean worm count, cestode $(\mathrm{P}<0.01)$ and mixed infection $(\mathrm{P}<0.05)$ values were higher in males (6.08 and 7.50) than females (4.27 and 5.65) respectively. However, no significant variation was observed between nematode adult worm burdens by sex of birds.

Table 1: Worm burden by chicken strain and sex

\begin{tabular}{lccccc}
\hline Variable & Number & EPG Mean \pm se & $\begin{array}{l}\text { Cestode } \\
\text { Mean } \pm \text { se }\end{array}$ & $\begin{array}{l}\text { Nematode } \\
\text { Mean } \pm \text { se }\end{array}$ & $\begin{array}{l}\text { Mixed infection } \\
\text { Mean } \pm \text { se }\end{array}$ \\
\hline Strain & & $* * *$ & $* *$ & $*$ & $*$ \\
Normal feather & 377 & $30.80 \pm 5.40^{\mathrm{b}}$ & $5.37 \pm 0.35^{\mathrm{ab}}$ & $1.56 \pm 0.27^{\mathrm{ab}}$ & $6.92 \pm 0.44^{\mathrm{ab}}$ \\
Fulani ecotype & 56 & $0.71 \pm 0.70^{\mathrm{c}}$ & $3.38 \pm 0.46^{\mathrm{b}}$ & $1.20 \pm 0.50^{\mathrm{b}}$ & $4.57 \pm 0.66^{\mathrm{b}}$ \\
Naked neck & 41 & $119.80 \pm 33.82^{\mathrm{a}}$ & $4.51 \pm 0.75^{\mathrm{b}}$ & $0.32 \pm 0.23^{\mathrm{b}}$ & $4.83 \pm 0.76^{\mathrm{ab}}$ \\
Dwarf & 21 & $62.86 \pm 30.18 \mathrm{a}^{\mathrm{b}}$ & $2.00 \pm 0.53^{\mathrm{c}}$ & $3.29 \pm 1.42^{\mathrm{a}}$ & $5.29 \pm 1.46^{\mathrm{ab}}$ \\
Frizzled & 45 & $114.18 \pm 45.32^{\mathrm{a}}$ & $7.96 \pm 1.75^{\mathrm{a}}$ & $0.31 \pm 0.19^{\mathrm{b}}$ & $8.27 \pm 1.83^{\mathrm{a}}$ \\
Sex & & $* *$ & $* *$ & $\mathbf{N S}$ & $* *$ \\
Male & 274 & $60.55 \pm 10.85^{\mathrm{a}}$ & $6.08 \pm 0.46^{\mathrm{a}}$ & $1.43 \pm 0.28$ & $7.50 \pm 0.55^{\mathrm{a}}$ \\
Females & 266 & $24.21 \pm 5.48^{\mathrm{b}}$ & $4.27 \pm 0.36^{\mathrm{b}}$ & $1.37 \pm 0.30$ & $5.65 \pm 0.46^{\mathrm{b}}$ \\
\hline
\end{tabular}

Mean \pm se with different superscript within column between each parameter differ significantly, ${ }^{*}=\mathrm{P}<0.05$, $* *=\mathrm{P}<0.01, * * *=\mathrm{P}<0.001, \mathbf{E P G}=$ egg per gramme

The PCV values did not vary significantly by strain. The $R B C$ values in chickens varied significantly $(\mathrm{P}<0.05)$ with strain. Highest RBC value was recorded in Fulani ecotype (4.67), followed by naked neck (4.00), dwarf (3.91), normal feathered (3.53) and frizzled (2.89) (Table 2). Values of the leucocyte counts (neutrophyl, monocytes, eosinophyl, basophyl and lymphocytes) are presented in Table 2. Neutrophyl values did not vary significantly with strain. However significant $(\mathrm{P}<0.05)$ difference was observed between strains in the number of monocytes. The highest counts $(1.33 \%)$ was in normal feathered chickens followed by Fulani ecotype $(0.71 \%)$, naked neck
$(0.67 \%)$, fizzled $(0.35 \%)$ and dwarf $(0.20 \%)$. Percentage lymphocytes distribution showed that dwarf had significantly $(\mathrm{P}<0.05)$ higher lymphocytes count $(51.0 \%)$ than the normal $(47.17 \%)$, Fulani ecotype (39.29\%), naked neck $(44.67 \%)$ and frizzled (43.0\%) chickens.

There was significant $(\mathrm{P}<0.05)$ difference among strains with respect to plasma albumin. The highest plasma albumin value was recorded in dwarfs $(2.13 \mathrm{~g} / \mathrm{dL})$, followed by frizzled $(1.92 \mathrm{~g} / \mathrm{dL})$, Fulani ecotype (1.61g/dL), normal $(1.39 \mathrm{~g} / \mathrm{dL})$ and naked neck $(1.38 \mathrm{~g} / \mathrm{dL})$. The values of plasma protein differed $(\mathrm{p}<0.01)$ among the chicken strains from $4.50 \mathrm{~g} / \mathrm{dL}$ in naked neck to $6.61 \mathrm{~g} / \mathrm{dL}$ in dwarf chicken. 
Variation in helminth susceptibility of indigenous chickens

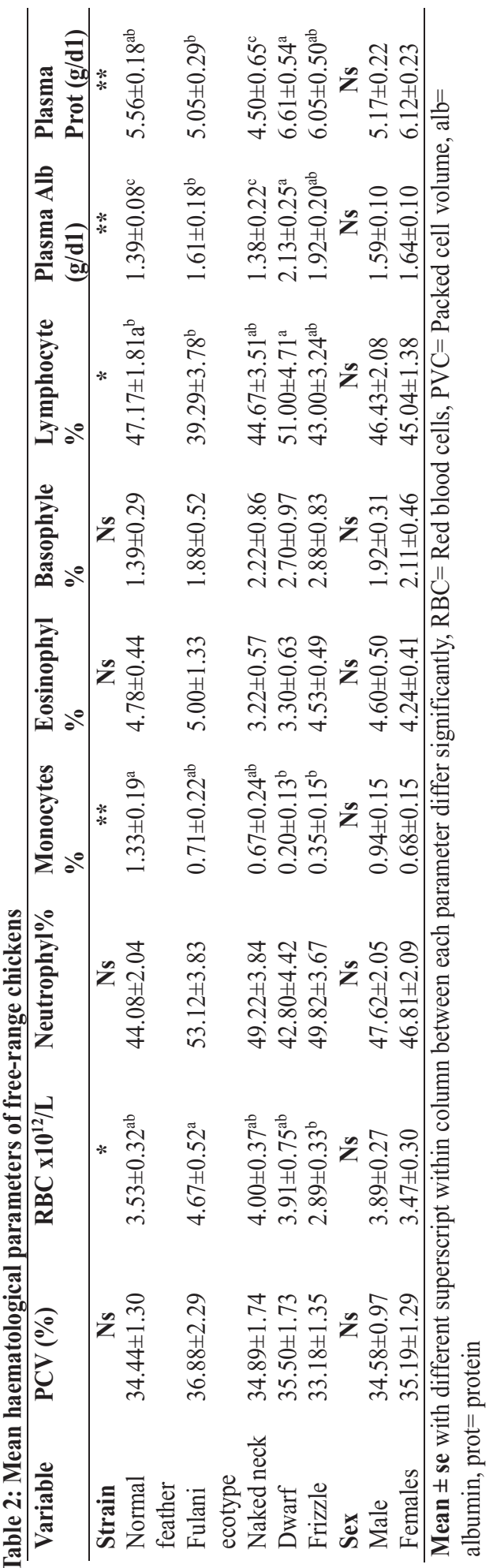




\section{Ibrahim, Mbap, Ibrahim and Mancha}

Relationships among some helminth and haematological parameters

The Pearson correlation coefficients among chickens' helminth and haematological indices are presented in Table 3 . There were generally negative and low correlations between egg and adult worm counts with haematological indices considered. However, most correlation values between egg (EPG) and adult worm counts and, within the latter were generally positive, significant $(\mathrm{P}<0.01)$ and fairly high.

Table 3: Correlations between helminth parasites and blood parameters of free-range chickens

\begin{tabular}{|c|c|c|c|c|c|c|c|c|}
\hline & EPG & $\begin{array}{l}\text { Nematode } \\
\text { count }\end{array}$ & $\begin{array}{l}\text { Cestode } \\
\text { count }\end{array}$ & MI & PCV & $\mathrm{RBC}$ & Eosinophyl & Albumin \\
\hline EPG & - & & & & & & & \\
\hline Nematode & $0.474 * *$ & - & & & & & & \\
\hline Cestode & $0.274 * *$ & 0.012 & - & & & & & \\
\hline MI & $0.466 * *$ & $0.554 * *$ & $0.797 * *$ & - & & & & \\
\hline PCV & -0.052 & 0.006 & -0.152 & -0.063 & - & & & \\
\hline $\mathrm{RBC}$ & -0.158 & -0.001 & -0.074 & 0.038 & 0.109 & - & & \\
\hline Eosinophyl & -0.161 & -0.127 & 0.083 & -0.015 & -0.096 & 0.077 & - & \\
\hline Albumin & 0.060 & -0.035 & 0.131 & 0.107 & -0.095 & 0.061 & 0.029 & - \\
\hline Protein & -0.079 & -0.203 & 0.001 & -0.095 & -0.028 & -0.125 & 0.048 & $0.455^{* *}$ \\
\hline
\end{tabular}

Table 4: Genetic Differentiation ( $F_{\text {ST }}$ below diagonal) and Gene flow (above diagonal) of indigenous chicken strains

\begin{tabular}{llllll}
\hline Populations & $\begin{array}{l}\text { Normal } \\
\text { feathered }\end{array}$ & Fulani ecotype. & Naked neck & Dwarf & Frizzled \\
\hline Normal feathered & $* * * *$ & 5.356 & 4.670 & 5.752 & 5.473 \\
Fulani ecotype & 0.047 & $* * * *$ & 5.312 & 5.503 & 3.554 \\
Naked neck & 0.053 & 0.041 & $* * * *$ & 4.205 & 8.789 \\
Dwarf & 0.049 & 0.054 & 0.052 & $* * * *$ & 3.678 \\
Frizzled & 0.042 & 0.064 & 0.029 & 0.058 & $* * * *$ \\
\hline
\end{tabular}

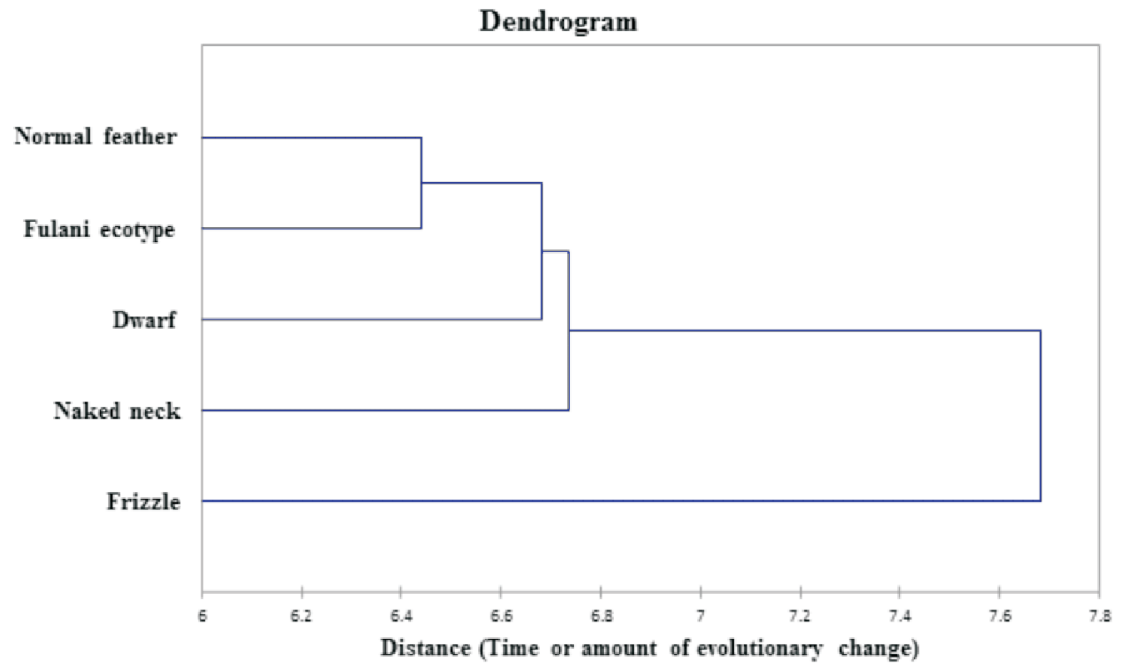

Figure 1. Dendrogram of relationships among 5 strains of chicken using Nei's (1978) genetic distance and Neighbour-joining methods. 


\section{Discussions}

\section{Effect of strain on worm count}

Variation in helminth infection has been established in this study by comparing the 5 strains of chickens. Based on EPG, Fulani ecotype and normal feathered chickens had the lowest worm burden. As already stated in our previous report, these two strains were genetically closer than others. Gradation in EPG for the other strains was also according to the genetic distance study (Dendrogram figure 1). The naked neck and frizzled chickens had the highest EPG. These two strains were also genetically closer at the other end of dendrogram. Furthermore, the high gene flow and low $\mathrm{F}_{\text {ST }}$ between Fulani ecotype and normal feathered and, naked neck and frizzled (Table 4) has in addition buttressed the assertion that the similarity in EPG between them were because of genetic closeness. Thus it could be firmly stated that susceptibility to worm burden in the study measured by EPG was genetically controlled. This is consistent with the findings of many researchers that immunity and susceptibility to diseases in chickens may be genetically determined (Bumstead and Barrow, 1993; Okoye and Aba-Adu Lugba, 1998; Poulsen et al., 1998). Though, acquired immunity could play a part. Investigation into the immune system has shown that chickens have the ability to expel worms (Permin et al., 1999). Variations in adult worm burden (cestodes, nematodes and mixed infection) by strain though significant, did not readily correspond to the genetic strain relationships. That there was significant strain variation in worm burden in this study agrees with Urquhart et al. (1988). It has been established that the Fulani ecotype is heavier than the other Nigerian chicken strains and as in the present study usually exhibits lower worm burden (Sonaiya, 2013). This is in agreement with Ackert et al. (1935) that heavy chicken breeds are less susceptible than light ones. It however contradicts the report that larger host harbour more gastrointestinal helminths because they consume more food and therefore are more likely to ingest higher quantity of infective stages (Nalubambe et al., 2015). In view of this contradiction, it can be stated that the mechanism of difference in strain susceptibility is not yet well known.

Furthermore, understanding host immune response to helminths is also essential in functional characterization of strains (Dominik et al., 2010; Matika et al., 2011; Silva et al., 2012).

\section{Effect of sex}

Overall, males had higher worm burden than females. This corroborates the findings of Urquhart et al. (1988) and Klein (2000a, b), and that it may be due to sex steroid which modulate several aspect of host immunity. More so, Todd and Hollingwilt (1951) reported that female chickens had lower worm burden and concluded that sex hormones might be an important factor in the development of parasite population.

\section{Packed cell volume}

The haematocrit or packed cell volume is a component of the blood parameters. Its evaluation is essential for determining the state of health of a bird. The pattern of PCV distribution in the present study was similar among chicken strains and fall within the normal physiological range reported by Jain (1993).

The PCV was slightly higher in Fulani ecotype chickens which exhibited the least helminth infection. It has been reported that $\mathrm{PCV}$ is somewhat higher in resistant than susceptible ecotypes, but not in all the cases (Gray, 1995). In a study with rams, Gruner et al. (2002) found that resistant rams had higher burden than susceptible ones and stated that if feacal egg counts were ambiguous, then adult worm count and PCV could be helpful in evaluating host susceptibility to helminth parasite. 


\section{Ibrahim, Mbap, Ibrahim and Mancha}

\section{Red blood cells}

Red blood cells (erythrocytes) serve as carrier of haemoglobin. Haemoglobin reacts with blood to form oxyhaemoglobin (Johnston and Morris, 1996). The variation in the RBC values in the present study is in agreement with the report of Duke, (1955) and Islam et al. (2004) that haematological values are influenced by breed. The values recorded in the present study are within the physiological range of $2.2-4.0 \times 10^{12} / \mathrm{L}$ (Schalm, 1975).

In a study conducted by Peters et al. (2011) on variation in haematological parameters of Nigerian native chickens; normalfeathered birds had higher mean values compared to frizzle and naked neck strain. This differs from the present study where Fulani ecotype had the highest mean value compared with the other strains. Similarly, Agaie and Uko (1998); Islam et al. (2004); Chineke et al. (2006) and Peters et al. (2011) observed some strain differences. However, the observed low values of RBC count in some strains of chicken in the present study could be as a result of higher worm burden associated with them. Aade et al. (2011) found in chickens infected with cestode showed lower RBC values and related immune status. Similarly, Misra et al. (1996) also observed decreased haemoglobin and RBC counts in lambs infected with nematode.

\section{Differential leucocytes count}

The major function of the WBC and other differentials counts is to defend the body by phagocytosis against invasion by foreign organisms and to produce, transport and distribute antibodies in immune response (Etim et al., 2014). Animals with high WBC and leucocytes counts are capable of generating high volume of antibodies during phagocytosis and have high degree of resistance to disease (Soeten et al., 2013) and enhance adaptability to local environment (Kabir et al., 2011; Isaac et al., 2013). The differential leucocytes reported in the present study are lower than the values reported by Islam et al. (2004). However, they are similar to the values reported by Oyewale (1987) in Nigerian local fowls.

Higher monocytes counts might have been recorded in normal feathered chickens in this study due to more infection by nematodes. Dhanalakshmi et al. (2002) reported that sheep infected with Strongyles (nematode) had significantly higher monocytes counts. Monocytes (which are agranulocytes of WBC) values were within the normal range, from 0.06 to $5.0 \%$ for chickens (Riddell, 2011). Islam et al. (2004) reported monocyte value of $3.42 \%$ for local chickens of Bangladesh, $6 \%$ in Kashmir, Bank, (1974) and 1 to $2 \%$ in Nigeria (Afolabi etal., 2011).

There was no significant difference among the five strains of chickens relative to eosinophyl. Different reports however exist on level of eosinophils in resistant and susceptible breeds. Pernthaner et al. (1996) reported that there was higher circulating eosinophyl in resistant than susceptible animals. But, Buddle et al. (1992) reported that decrease level of eosinophil is associated with susceptibility to nematode infection. Eosinophils are multifunctional cells. Their primary function is considered to be defence against organisms that are too large to be phagocytosed, particularly parasitic helminths. Butterworth (1984), hypothesized that the primary function of eosinophils in defending hosts against infection by relatively large organisms is based on the accumulation of observations that eosinophils degranulate and can kill helminths in vitro in the presence of antibody and/or complement; they move from the blood and aggregate in the locality of helminths in vivo; large numbers of eosinophils are often observed in close association with both intact and damaged helminths in vivo; and they degranulate in the vicinity of, or on to the surfaces of, 


\section{Variation in helminth susceptibility of indigenous chickens}

helminths in vivo. Eosinophils are involved in animal pathological response and are inevitably present in large numbers in inflammatory lesions associated with helminth infections or allergic conditions. However, Woolaston et al. (1996) stated that the role of eosinophyl is unclear and may vary in host parasite system (Meusen and Barlie, 2000). Following infection, eosinophyl move from the bone marrow through blood to the tissue and only a quantity goes into gastrointestinal tract and instant in regulating growth of parasites (Henderson and Stear, 2006). They further reported that aallergic or parasitic conditions may show increased numbers of eosinophils. Lymphocytes are usually the most numerous and frequent WBC type followed by heterophiles, eosinophils and monocytes. They are the key elements in the production of immunity. Dwarf chickens had significantly higher lymphocytes than the other four groups. This contradicts the reports of Dhanalakshmi et al. (2002) that animals infected with nematode had lower lymphocyte counts, since in the present study, dwarf chickens had higher nematode burden than others. The lymphocyte values in this study are within the normal physiological range of $20-50 \%$ for healthy chickens (Duke, 1955). However, the relatively high values of lymphocytes and neutrophils counts in this study are consistent with the findings of Sturkie (1965) and Afolabi et al. (2011). However, available information indicates that haematological values of avian species are significantly influenced by poultry diseases including parasites (Juranova et al., 2001).

\section{Plasma albumin and protein}

Albumin is the largest single protein fraction in healthy birds synthesized in the liver and serves as the major reservoir (Sahu, 2014). In this study, plasma albumin variations were similar to that of total plasma protein and were low. They are lower than the normal values $6.0-8.5$ and
2.9 - 3.9 g/dl respectively (Cole, 1986). Gadre et al. (2008) reported that low albumin and total proteins are usually due to parasites and haemorrhage that may lead to anaemia. In particular, albumin is a negative acute phase protein and its concentration decreases during inflammation and parasite infection (Majabi, 2000; Stockham and Scott, 2002). In humans, children with helminth infection were found to have low blood albumin and total proteins (Bashir et al., 2012). Northop (1987) showed that albumin concentration increased significantly after anthelmintics treatments in children infected with parasites. More so, increase in albumin concentration is associated with dehydration and decrease occurs with lower synthesis (in chronic liver diseases, dietary protein deficiency, renal disease, and gastrointestinal disease (Margaret and Wissan, 2001). Although the mechanism of reduction in the albumin and protein concentration in the blood is not well known, it has been suggested that intestinal parasitism increases albumin catabolism (Tanwar and Mishra, 2001). This is probably due to reduced energy intake during parasitism thus proteins are mobilized to supply the needed amount (Crompton and Nesheim, 2002). Plasma proteins are essential components of the blood and play a crucial role in maintaining homeostasis (Okwonkwo et al., 2011). Changes in plasma protein are common clinical symptoms of gastrointestinal parasitism (Harvey, 1975). That total plasma protein in dwarf and frizzle chickens were highest, but Fulani ecotype and naked neck had least values is contrary to Ladokun et al. (2008) and Ibrahim et al. (2012). They reported higher protein levels in normal feathered than other strains of local chickens. This according to them may be due to infection differences. Yon Brand (1973) reported that changes in the serum protein levels are characteristic features of parasitic infections. He also observed that 


\section{Ibrahim, Mbap, Ibrahim and Mancha}

variations in serum protein depended on stages or severity of an infection and the host species. Plasma protein loss had also been associated with helminth infection in sheep and goat (Yacob et al., 2008). A slight decline in the serum protein level during ascariasis in children had also been reported (Venkatachalam and Patwardhan, 1953). Sadun and Willams (1986) also reported decreased serum protein level in albino rats during experimental schistosomiasis. On the other hand, increased serum protein level was observed by Khadoon and Ansari (1979) in buffalo calves with Setaria cervi infection.

Relationships among some helminth and haematological parameters

Haematological parameters have been used to evaluate worm infection (Nalumbamba et al., 2015). There were few positive correlations between worm burden and haematological parameters eg plasma albumin and cestode, or total worm count. This shows that there might have been increases in their haematological parameters in response to infection probably to combat the situation. On the other hand, negative correlations e.g. between EPG and PCV, RBC, eosinophyl, plasma protein and, albumin might have been due to loss of blood parameters due to the combating situations. The negative correlations between PCV, RBC and eosinophyl with EPG have been documented (Albers et al., 1990; Baker et al., 2003). They further concluded that it is ideal to select for higher PCV and decreased EPG. More so, Yadav et al. (1993) observed that PCV level was significantly lower in relation to higher faecal egg count and worm burden of $H$. contortus in sheep. They also reported that damage of gastrointestinal mucosa caused by gastrointestinal nematodes resulted in leakage of plasma protein causing hypoproteinemia and loss of body weight. Similarly, significant decline in PCV and increase in total neutrophil and eosinophil count were observed in sheep experimentally infected with $H$. contortus (Saddiqi, 2010). Furthermore, Dominik (2005) reported that gastro-intestinal helminth infection in sheep was incriminated as the cause of declined level of total erythrocyte count, packed cell volume (PCV) and lymphocyte count. They further reported that gastro-intestinal parasites caused development of immature cells which led to formation of weak cell junctions in the host body. Some studies have however shown that helminth burden did not have much effect on plasma albumin probably due to the ability of the host to balance the relationship between their nutritional requirement and the losses through helminth infestation (Moore and Hopkins, 2009; Cripps et al., 2014).

A prominent feature of this study was the complete absence of trematodes. This is in conformity with the works of Fabiyi, (1972) and Yoriyo et al. (2005) which did not find any trematodes among birds examined in different parts of northern Nigerian. It is concluded that chicken strains used responded differently to the helminth infection, which may be attributed to their differences in their natural or acquired resistance. The Fulani ecotype was the least susceptible to helminth parasites followed by normal feathered chickens. Therefore, the Normal feathered and Fulani ecotype have been showed to be less susceptible to worm and should be utilized in any effort to improved resistance to helminth infection in chickens.

\section{Conclusion}

It is concluded that chicken strains used responded differently to the helminth infection, which may be attributed to their differences in their natural or acquired resistance. The Fulani ecotype was the least susceptible to helminth parasites followed by normal feathered chickens. The normal 
feathered and Fulani ecotypes were the most closely related strains, though the five strains had common ancestry.

\section{References}

Aade, U., Wankhede, H. and Kaldate, K. 2011. Haematological parameters change in Gallus gallus domesticus infected with Cotugnia digonopora. Recent Research in Science and Technology, 3: 16-22.

Abdelqader, A., Gualy, M., Wollny, C. B. A. and Abo-Shehada, M. P. 2008. Prevalence and burden of gastrointestinal helminths among local chickens in northern Jordan. Preventive Veterinary Medicine, 85: 17-22.

Ackert, J. E. and Eisenbrandt, L. L. 1935. Comparative resistance of Bronze Turkeys and White Leghorn chickens to the intestinal nematode, Ascaridia lineata (Schneider). Journal of Parasitology, 35: 200204.

Afolabi, K. D., Akinsoyinu, A. O., Abdullah, A. R. O., Olajide, R. and Akinleye, S. B. 2011. Haematological parameters of the Nigerian local grower chickens fed varying dietary levels of palm kernel cake. Poljoprivreda, 17: (1) 74-78.

Agaie, B. M., and Uko, O. J. 1998. Effect of season, sex, and species difference on the packed cell volume (P.C.V.) of guinea and domestic fowls in Sokoto, Sokoto state of Nigeria. Nigerian Veterinary Journal, 19: 95-99.

Albers, G. A. A., Gray, G. D., Le Jambre, L.F., Barger, I.A. and Baker, J.S.F. 1990. The effect of Haemonchus contortus infection on haematological parameters in young Merino sheep and its significance for productivity.
Animal Production, 50:99-101.

Alipanah, M., Torkamanzehi, A., Amiry, Z. and Rabani, F. 2011. Study of genetic diversity of Dashtiari, Khazak and Zabol chickens using microsatellite markers. Trakia Journal of Sciences, 9 (2): 76-81.

Baker, R. L., Nagda, S., Rodriguez Zas, S. L., Southey, B. R., Audho, J. O., Aduda, E. O. and Thorpe, W. 2003. Resistance and resilience to gastro-intestinal nematode parasites and relationships with productivity of Red Maasai, Dorper and Red Maasai and Dorper crossbred lambs in the sub-humid tropics. Animal Science, 76: 119136.

Bashir, A. L., Fayaz, A. and Hidayatullah, Tak. 2012. Impact of helminth parasites on plasma proteins in children of Kashmir. International Journal of Innovation Sciences and Discoverie, 1 (1): 014-016.

Buddle, B. M., Jowett, G., Green, R. S., Douch, P. G. C. and Risdon, P. L. 1992. Association of blood eosinophilia with the expression of resistance in Romney lambs to nematodes. International Journal of Parasitology, 22:955-960.

Bumstead, N., and Barrow, P. 1993. Resistance to Salmonella gallinarum, S. Pullorum and $S$. enteritidis in inbred lines of chickens. Avian Diseases. 37: 189 193.

Butcher, G. D., and Miles, R. D. 1992. Intestinal parasites in backyard chicken flocks. Publication VM76 Florida Cooperative Extension Services, p. 1-3

Butterworth, A. E. 1984. Cell-mediated damage to helminths. Advances in Parasitology, 23: 143-235.

Chineke, C. A., Ologun, A. G., and Ikeobi，C. O. N. 2006 . 


\section{Ibrahim, Mbap, Ibrahim and Mancha}

Haematological parameters in rabbit breeds and crosses in humid tropics. Pakistan Journal of Biological Sciences, 9(11): 21022106.

Coles, E. H. 1986. Veterinary Clinical Pathology, $3^{\text {rd }}$ edition. W.B Saunders Company. Philadelphia, pp 394.

Cripps, J., Beveridge, I., Ploeg, R. and Coulson, G. 2014. Impacts of a parasite community in juvenile kangaroos. International Journal of Parasitology, Parasites and Wildlife, 3: 88- 94.

Crompton, D. W. T. and Neisheim, M. C. 2002. Nutritional impact of intestinal helminthiasis during the human life cycle. Annual Review Nutrition, 22: 35-59.

Dhanalakshmi, H., Jagannath, M. S. and Souzaplacid, E. D. 2002. Multiple anthelmintics resistances in gastrointestinal nematodes of sheep. Journal of Veterinary Parasitology, 17: 89-91.

Dominik, S. 2005. Quantitative trait loci for internal nematode resistance in sheep: a review. Genetic Selection and Evolution, 37:83-96.

Dominik, S., Hunt, P. W., McNally, J., Murrell, A., Hall, A. and Purvis, I. W. 2010. Detection of quantitative trait loci for internal parasite resistance in sheep. I. Linkage analysis in a Romney_Merino sheep backcross population. Parasitology, 137: $1275-1282$.

Dube, S., Zindi, P., Mbanga, J. and Dube, C. 2010. A study of scavenging poultry gastrointestinal and ectoparasites in rural areas of Matebeleland Province, Zimbabwe. International Journal of Poultry Science, 9(9): 911-915

Dukes, H. H. 1955. The Physiology of
Domestic Animals. (7th ed.). Baillers Tindall and Co. London.

Dunn A. M. 1978. Veterinary Helminthology. Willi a m Heinemann Medical Books LTD. London, UK.

Etim, N. N., Williams, M. E., Akpabio, U. and Offiong, E. E. A. 2014. Haematological parameters and factors affecting their values. Agricultural Science, 2: 37-47.

Fabiyi, J. P. 1972. Incidence of Helminth parasites of the domestic fowl in Vom area of Benue-Plateau State Nigeria. Bulletin of Epizotic Disease in Africa, 20: 229-233.

Gadre, A. S., Maske, D. K., Panchbhai, C. G., Gawande, T. R., Kolte, S. W. and Sirothia, A. R. 2008. Haematological changes in naturally infested dairy animal at central zone of Vidarbha. Veterinary World. 1(2):47-48.

Gray, G. D. 1995. Genetic Variation in Resistance to Parasites. In: G. D. Gray, R. R. Woolaston, and B. T. Eaton ed., Breeding for Resistance to Infectious Diseases in Small Ruminants. Canberra, ACIAR, 4352.

Gruner, L., Cortet, J., Sauve, C., Limouzin, C. and Brunel, J. C. 2002. Evolution of a nematode community in grazing sheep selected for resistance and susceptibility to Teladorsagia circumcincta and Trichostrongylus colubriformis: a 4-year experiment, Veterinary Parasitology, 109:277-291.

Harvey, W. R. 1975. Least squares Analysis of Data with Unequal Subclass Numbers. Agriculture Research Services. U.S Department of Agriculture, Wahington, D. C.

Henderson, N. G. and Stear, M. J. 2006. 
Eosinophil and $\operatorname{IgA}$ responses in sheep infected with Teladorsagia circumcincta, Veterinary I $m$ m $u$ n o l o g y and Immunopathology, 112: 62-66.

Hodasi, J. K. M. 1978. Comparative studies on the helminth fauna of Native and introduced domestic fowls in Ghana. Journal of Helminthological, 43:35-52.

Ibrahim, A. A., Aliyu, J., Wada, N. I. and Hassan, A. M. 2012. Effect of sex and genotype on blood serum electrolytes and biochemical parameters of Nigerian indigenous chickens. Iranian Journal of Applied Animal Science, 2(4): 361365.

Isaac, L. J., Abah, G., Akpan, B., and Ek a e t t e, I. U . 2013 . Haematological properties of different breeds and sexes of rabbits. Proceedings of the 18th Annual Conference of Animal Science Association of Nigeria, Abuja Nigeria. 8 - 12 September 2013 Pp.24-27.

Islam, M. S., Lucky, N. S., Islam, M. R., Ahad, A., Das, B. R., Rahman, M. M. et al. 2004. Haematological Parameters of Fayoumi, Assil and Local chickens reared in Sylhet Region in Bangladesh. International Journal of Poultry Science, 3(2):144-147.

Iqbal, Z., Khan, M. N., Kafar, M. A. and Jabbar, A. 2004. A critical analysis of parasitic research on some domesticated animals of Pakistan. Journal of Applied Emtomology Science, 1 (1): 1 - 14.

Jain, N. C. 1993. Essentials of Veterinary Haematology. Philadelphia, Lea and Febiger. Pp 13- 53.

Johnston, J. K., and Morris, D. D. 1996. Alterations in blood proteins. In: B. P. Smith (Ed.), International
Animal Medicine (2nd Ed.). USA: Mosby Publishers.

Jordan, F. T. M., and Pattison, M. 1996. Poultry Diseases. 4th edition, $\mathrm{Pp}$ 283-286.

Juranova, R., Nga, N. T., Kulikova, L. and J u r a j d a , V. 2001 . Pathogenicity of Czech isolates of infectious bursal disease virus. Acta Veterinaria Brno, 70: 425431.

Kabir, M., Akpa, G. N., Nwagu, B. I., Adeyinka, I. A., and Bello, U. I. 2011. Sexual dimorphism, breed and age characteristics of rabbits in Zaria, Nigeria. Proceedings of the 16th Annual Conference of Animal Science Association of Nigeria, September, 12-15, Anyigba, Kogi State, Nigeria. Pp 133-137.

Khadtoon, H. and Ansari, J. A. 1979. Biochemical studies on blood alteration in experimental Setaria cervi infection. Helminthologia, 17: $167-206$.

Klein, S. L. 2000a. The effects of hormones on sex differences in infection: from genes to behavior. Neuroscience Biobehaviour Review, 24:627-638.

Klein, S. L. 2000b. Hormones and mating system affect sex and species differences in immune function among vertebrates. Behaviour Processes, 5:149-166.

Ladokun A. O., Yakubu A., Otite J. R., Omeje J. N., Sokunbi O. A. and Onyeji E. 2008. Haematological and biochemical indices of naked neck and normally feathered Nigerian indigenous chickens in a sub humid tropical environment. International Journal of Poultry Science, 7(1): 55-58.

Lamidi, A. W., Abiola, S. S., Ozoje, M. A., Adeyemi, O.A. and Ojelade, A. Y. 
P. 2014. Effect of egg size on hatching and post-hatch performance of indigenous chickens. Nigerian Journal of Animal Production, 41(1): 77-83.

Mafu, J. V., and Masika, P. J. 2003. Smallscale broiler production by rural farmers in the central Eastern Cape Province of South Africa. Fort Hare Papers, 12 (1): 25-34.

Matika, O., Nyoni, S., van Wyk, J. B., Erasmus, G. J. and Baker. R. L. 2003. Resistance of Sabi and Dorper ewes to gastro-intestinal nematode infections in an African semi-arid environment. Small Ruminant Research, 47:95-102.

Matur, B., Dawam, N. and Malann, Y. 2010. Gastrointestinal helminth parasites of local and exotic chickens slaughtered in Gwagwalada, Abuja (FCT), Nigeria. New York Science Journal, 3(5): 96-99.

Meeusen, E. N., and Balic, A. 2000. Do eosinophils have a role in the killing of helminth parasites. Parasitology Today, 16:95-101.

Mojabi, A., 2000. Veterinary Clinical Biochemistry (in Farsi), $2^{\text {nd }}$ ed. Noorbakhh Press, Tehran, 149-444.

Moore, I. T. and Hopkins, W. A. 2009. Interactions and trade-offs among physiological determinants of performance and reproductive success. Integrated and Compative Biology, 49: 441-451.

Muchadeyi, F. C., Sibanda, S., Kusina, N. T., Kusina, J. and Makuza, S. 2004. The village chicken production system in Rushinga District of Zimbabwe. Livestock Research for Rural Development 16 www.Irrd.org/Irrd16/6/much1604 0htm. Accessed 3- 5-2015.

Mukaratirwa, S. and Hove, T. 2009. A survey of ectoparasites, cestodes and management of free-range indigenous chickens in rural Zimbabwe. Journal of South African Veterinary Association, 80: 188-191

Nalubamba, K. S., Bwalya, E. C., and Saasa, N. 2015. Association between helminth burden, helminth species richness, body condition, haematological profile and spleen morphometrics in domestic guinea fowl (Numida meleagris). International Journal of Poultry Science, 14 (4): 196-202.

Northrop, C. A., Lunn, D. G., Wainwright, $M$. and Evans, $J$. 1987 . Plas ma a lbumin concentrations and intestinal permeability in Bangladeshi children infected with Ascaris lumbricoides. Transactions of the Royal Society of Tropical Medicine and Hygiene, 81: 811-815.

Okonkwo, J. C., Omeje, J. S. and Okonkwo, I. F. 2011. Effect of source and sex on blood protein fractions of West African dwarf goats (WADG). Research Opinion in Animal and Veterinary Science, 1(3): $158-161$.

Okoye, J. D. A. and Aba-Adulugba, E. P. 1998. Comparative study of the resistance or susceptibility of local Nigerian and exotic chickens to infectious bursal diseases. Avian Pathology, 27:168-173.

Olofin, E. A., 2017. The physical setting. In E. A. Olofin, A. B. Nabegu and A. M. Dambazau (Eds). Wudil within Kano Region: A Geographical Synthesis (pp 5-34). Kano City: Adamu Joji Publishers.

Oyewale, J. O. 1987., Haematological and Plasma biochemical values of two breeds of domestic fowl in a tropical environment. Animal 
Technology, 38: 49-53.

Pandey, V. S., Demey, F. and Verhulst, A. 1992. Parasitic Diseases: a neglected problem in village poultry in Sub-Saharan Africa. pp. 136-141. In: Pandey, V.S. and Demey, F. (Eds) Conference Proceeding of Village Poultry Production in Africa. 7 - 11 May, Rabat, Morocco, Pp 136-141.

Permin, A., and Hansen, J. W., 1998. Epidemiology, diagnosis and control of poultry parasites. Food and Agricultural Organization of the United Nations, Animal Health Manual No. 4, Rome.

Permin, A., Bisgaard, M., Frandsen, F., Pearman, M., Nansen, P., and Kold. J., 1999. The prevalence of gastrointestinal helminths in different poultry production systems. British Poultry Science, 40: 439-443.

Permin, A., Bojesen, M., Nansen, P., Bisgaard, M., Frandsen, F., and Pearman, M., 1997. Ascaridia galli populations in chickens following single infections with different dose levels. Parasitological Research, 83: 614617.

Pernthaner, A., Cole, S. A., Morrison, L. Green, R., Shaw, R. J., and Hein, W .R. 2006). Cytokine and antibody subclass response in the intestinal lymph of sheep during repeated experimental infections with the nematode parasite Trichostrongylus colubriformis. Veterinary Immonology and Immunopathology, 114:135-148.

Peters, S. O., Gunn, H. H., Imumorin, I. G., Agaviezor, B. O., and Ikeobi, C. O., 2011. Haematological studies on frizzled and naked neck genotypes of Nigerian native chickens. Tropical Animal Health
Production, 43(3), 631-638.

Pinckney, R. D., Coomansingh, C., Bhaiyat, M. I., Chikweto, A. and Sharma, R., 2008. Prevalence of gastrointestinal parasites in freerange poultry in Grenada, West Indies. West Indian Veterinary Journal, 8 (1): 23-26.

Poulsen, D. J., Thureen, D. R. and Keeler, Jr. C. L. 1998. Comparison of disease susceptibility and resistance in three lines of chickens experimentally infected with infectious layngotrcheitis virus. Poultry Science, 77: 17-21.

Preston, J. M., and Allonby. E. W., 1978. The influence of breed on the susceptibility of sheep and goats to a single experimental infection with Haemonchus contortus. Veterinary Research, 103:509-512.

Riddell, C., 2011. Comparative Anatomy, Histology and Physiology of the Chicken. Department of Pathology, Western College of Veterinary Medicine, University of Saskatchewan, Saskatoon, Saskatchewan, Canada S7N 0W0. Retrieves January 11, 2016. http://cal.vet.upenn.edu/projects/ poultry/Syllabus/page37_44.htm.

Saddiqi, H. A., Iqbal, Z., Khan, M. N., and Muhammad, G., 2010. Comparative resistance of sheep breeds to Haemonchus contortus in a natural pasture infection. International Journal of Agriculture and Biology, 12: 739-743.

Sadun, E. H., and Williams, J. S., 1986. Biochemical aspects of Schistosoma mansoni in mice in relation to worm burdens and duration of infection. Experimental Parasitology, 18: 266-273.

Sahu, S., 2014. Alteration in serum protein profile in White Leghorn chicks 


\section{Ibrahim, Mbap, Ibrahim and Mancha}

with experimental different doses of infection of Ascaridia galli. International Journal of Pharmacy and Life Science, 5 (7): 3637-3642.

Schalm, O. W., Jain, N. C., and Carroll, E. J., 1975. Veterinary Haematology (3rd ed., p.15-218). USA: Lea and Fabiger, Philadelphia.

Silva, M. V. B., Sonstegard, T. S., Hanotte, O., Mugambi J. M., Garcia, J. F., Nagda, S., 2012. Identification of quantitative trait loci affecting resistance to gastrointestinal parasites in a double backcross population of Red Maasai and Dorper sheep. Animal Genetics, 43: 63-71.

Silva, P., Abeykone, N. D. F., Samaraweera, A. M., Han, J. L., Ibrahim, M. N. M., and Okeyo, A. M., 2012. Genetic diversity and adaptability exist among backyard poultry populations in Sri Lanka. Proceedings, a 10th World Congress of Genetics Applied to Livestock Production 17 - 22 August Vancouver, Canada.

Soetan, K. O., Akinrinde, A. S., and Ajibade, T. O., 2013. Preliminary studies on the haematological parameters of cockerels fed raw and processed guinea corn (Sorghum bicolor) (p. 49-52). Proceedings of 38th Annual Conference of Nigerian Society for Animal Production.

Sonaiya, E. B., 2013. Assessment of locally adapted chickens and scavengeable feed resources for family poultry transformation in Nigeria. In: Occasional Scientific Publications for Nigeria's Agricultural Transformation Agenda, in honour of Emeritus Prof. C. C. Nwosu. Pp 21-64.

Soulsby, E. J. L., 1982. Helminths,
Arthropods and Protozoans of Domesticated Animals (7th edn). Bailliere Tindale London

SPSS, 2010. Statistical Package for Social Science Procedures and Facilities, Release Inc 13.0 for Windows. New York.

Tanwar, R. K. and Mishra, S. 2001. Clinico-haemato-biochemical studies on intestinal helminthiasis in poultry. Veterinary Practitioner, 2: 137-140.

Tesfaheywet, Z., Amare, E., and Hailu, Z., 2012. Helminthosis of chickens in selected small scale commercial poultry farms in and around Haramaya Woreda, Southeastern Ethiopia. Journal of Veterinary Advances, 2(9): 462-468.

Todd, A. C., and Hollingsworth K. P., 1951. Host sex as a factor in development of Ascaridia galli. Experimental Parasitology, 1: 303304.

Urquhart, G. M., Armour, J. L., Dunn, A. M., and Jennings, F. W., 1996. Veterinary Parasitology. 5th Edn., Longman Scientific and Technical, UK.

Urquhart, G. M., Armour, J., Duncan, J. L., Dunn, A. M., and Jennings, F. W., 1987. Veterinary Parasitology. Longman Scientific and Technical: Essex, England, 307pp.

Urquhart, G. M., Armour, J., Dunncan, J. L., and Jennings, F. W., 1988. Veterinary Parasitology, 1st Ed., ELBS, Longman, London, U.K.

Venkatachalam, P. S., and Patwardhan, V. N., 1953. The role of Ascaris lumbricoides in the nutrition of the host effect of ascariasis on digestion of protein. Transaction of the Royal Society of Tropical Medicine and Hygiene. 47 (2): 169 -175 .

Woolaston, R. R., and Baker, R. L., 1996. 


\section{Variation in helminth susceptibility of indigenous chickens}

Prospects of breeding small ruminats for resistance to internal parasites. International Journal of Parasitology, 26: 845-855.

Yacob, H. T., Basazinew, B. K., and Basu, A. K., 2008. Experimental concurrent infection of Afar breed goats with Oestrusovis (L1) and Haemonchuscontortus (L3): Interaction between parasite populations, changes in parasitological and basic haematological parameters. Experimental Parasitology, 120: $180-184$.
Yadav, C. L., Grewal, H. S., and B a n e r j e e, D. P., 1993 . Susceptibility of two crossbreeds of sheep to Haemonchus contortus. International Journal for Parasitology, 23: 819-822.

Yon Brand, T., 1973. Biochemistry of Parasites. Academic Press, New York, U.S.A.

Yoriyo, K. P., Fabiyi, J. P., Adams, S. U. and Panda, S. M. 2005. Intensities of helminth parasites of free ranging chickens in Bauchi and Environs. Yankari Journal, 2, 135137.

Received: $19^{\text {th }}$ May, 2021

Accepted: $15^{\text {th }}$ August, 2021 